\title{
The Live Teaching Case: A New IS Method and its Application
}

\author{
Ann-Frances Cameron, Marie-Claude Trudel, Ryad Titah, \\ and Pierre-Majorique Léger \\ HEC Montréal, Montréal, Québec, Canada
}

\author{
Ann-frances.cameron@hec.ca, marie-claude.trudel@hec.ca, \\ ryad.titah@hec.ca, pierre-majorique.leger@hec.ca

\section{Executive Summary}

When teaching Information Systems (IS), one of the crucial objectives is to make students understand the practical aspects of the integration of IS in organizations. Over the last decades, several pedagogical approaches were introduced to more tightly bridge theory and practice, e.g., hands on exercises, simulations, real world projects, guest speakers, and case studies. In this paper, we introduce a pedagogical approach novel to IS which brings practice into the classroom, i.e., the live teaching case method. The live teaching case method is a hybrid between a guest speaker event and a teaching case. The live teaching case method is different from a written case as it is the animator who experienced the case who is verbally presenting the case. The live teaching case is different from a guest speaker event as it is more focused around specific decision points, such as a written case would be. We believe that the live teaching case approach alleviates several of the traditional case method shortcomings while maximizing the benefits associated with the presence of a guest speaker in class. This paper outlines the various steps involved in the live teaching case including initiating contact, planning the decision points, selecting student readings and developing pre-course materials, guiding the initial presentation and discussion, guiding the presentation and discussion of the managerial decision points, and class wrap-up. This approach is explained and then illustrated using three different IS courses, namely, an IS project management course, a systems analysis and design course, and a capstone course on enterprise system implementation.

Keywords: live case study, teaching case, guest speaker, hybrid.

\section{Introduction}

"There is a longstanding view that the practice of teaching should involve the teaching of practice" (Hackney, McMaster, \& Harris, 2003). This challenge of aligning teaching and practice exists for most subject matters. In information systems (IS), this challenge is amplified by several factors: (1) the frequency and intensity of technological changes, e.g., miniaturization, increase in

Material published as part of this publication, either on-line or in print, is copyrighted by the Informing Science Institute. Permission to make digital or paper copy of part or all of these works for personal or classroom use is granted without fee provided that the copies are not made or distributed for profit or commercial advantage AND that copies 1) bear this notice in full and 2) give the full citation on the first page. It is permissible to abstract these works so long as credit is given. To copy in all other cases or to republish or to post on a server or to redistribute to lists requires specific permission and payment of a fee. Contact Publisher@InformingScience.org to request redistribution permission. processing speed, decrease in the cost of equipment (most notably in the cost of digital storage), advent of the Internet followed by the Web 2.0, and mobile applications (Maglitta, 1996); (2) the higher technology savvy-ness of students starting their academic life as compared to elder generations (Tapscott, 2008); and (3) the more widespread view of technology as a strategic weapon rather than a simple tool within 
organizations (Rivard, Aubert, Patry, Paré, \& Smith, 2004). As a consequence, for IS graduates to be successful in today's environment, the requirements have become more complex as these graduates must now be experts in the ever-changing technological domain and expert decisionmakers for organizations facing technical challenges. They must be able to make business-related decisions in real-life situations where the solution is often not obvious and highly complex (Connolly \& Stansfield, 2006). In this perspective, the present paper advances a pedagogical method new to IS that has the ability to more realistically convey the practical and conceptual challenges that will be faced by new IS graduates, while at the same time offering a powerful tool for developing the high-level IS capabilities identified within the official 2010 Information Systems curriculum (Topi et al., 2010).

In this paper, we first outline the teaching case and invited guest speaker methods as well as their limits. We then explain the live teaching case method, a pedagogical approach novel to IS that maximizes the benefits of both the traditional teaching case and the invited guest speaker method. Three illustrations of how to apply the live teaching case method in three different courses that are part of the IS curriculum are provided. Finally, we highlight the contributions and limits of the live teaching case.

\section{The Teaching Case Method}

The teaching case method has been popular for many years. It uses descriptions of actual situations where students - taking the role of a person involved in the case - have to make a decision, solve a problem, meet a challenge, or develop an opportunity. These cases appeared in print form. ${ }^{1}$ In order to write a case, the case developer must first find an interesting situation to study. The organization is then visited and relevant data are collected. A case is usually incomplete without a teaching note, a document which guides instructors in their class preparation. The teaching note - which is not distributed to students - includes elements such as basic issues, teaching objectives, suggested student assignments (including answers), suggested classroom approach and timing, additional readings, and supplemental discussion points (Leenders, MauffetteLeenders, \& Erskine, 2001). Students typically read the case and prepare to discuss it in class. In class, the instructor poses questions and students discuss - often first in small teams and then with the whole group - the case questions.

The teaching case method has many benefits. The discussion-based format helps to develop selfconfidence, cooperation, and independent thinking. The case method is also a great approach for improving analytical, decision making, synthesis, listening, presentation, and time management skills (Kerr, Troth, \& Pickering, 2003; Mauffette-Leenders, Erskine, \& Leenders, 2001). Finally, the case method allows the students to learn by doing, which is believed to be one of the best ways to integrate new knowledge (Joplin, 1995).

The case method also has some limitations. First, the economic, social, political, and technological context of the case are usually absent from the text and must be inferred from its date and location. Very often, students do not have this knowledge and they fail to notice subtleties in the story. Second, the instructor's knowledge of the case is often limited to what is presented in the text and in the teaching note, which can limit the depth of discussion. In addition, cases with heavy technological content tend to lose their relevance more rapidly than other type of cases. As the technological context evolves, the discussion proposed in the teaching notes becomes out of date and less realistic. To use these cases, it is often necessary to tell the students to analyse the

\footnotetext{
${ }^{1}$ Although some multimedia cases have recently been produced (McAfee, Dessain, \& Sjoman, 2007), in this paper, when we refer to teaching cases we are referring to traditional-style written case studies with accompanying teaching notes that are used in class.
} 
case in its historical context, which is difficult and different from the original pedagogical objective. For example, in a case about Zara (McAfee et al., 2007), the company faced the decision to replace their DOS-based mobile devices and eventually decided not to upgrade; with the recent growth in mobile applications, this decision is unrealistic given today's technologies and it is difficult for students to grasp. Finally, and as a consequence of the previous shortcomings, students do not take the case seriously and may feel that it lacks in realism. When students do not take a case seriously, they may not engage with the case and not prepare adequately for class, resulting in weak participation in the class discussion (Huff \& Lucas, 2002, as cited in Kerr et al., 2003). Thus, the original discussion-based benefits of using such a case may fade.

\section{The Guest Speaker Method}

Another method that is frequently used in order to bridge the gap between theory and practice is the use of guest speakers from industry. In this method one or more IT professionals are invited to bring real world IT experience into the classroom. Several previous non IT-related studies have confirmed the merit of guest speaker events (Kamoun \& Selim, 2007). First, this teaching technique builds linkages between academics and the industry (Clarke \& Gibson-Sweet, 1998; Glenwick \& Chabot, 1991; Gordon, 1999) and provides professional role models for students (Butler, 1997). Second, guest speaker events greatly enhance students' practical and technical knowledge of a particular field as they get to hear about their specialization as it is actually practiced in industry (Butler, 1997; Glenwick \& Chabot, 1991; Leonard, 1980). As an outsider, the speaker provides a different perspective from that of academia (Olson, 1988), which students appreciate. Third, guest speaker events provide an opportunity for educators to actively learn about the world outside the campus, which allows educators to better integrate their academic knowledge with concrete experiences (Boyer, 1997). Educators can also use the presence of a guest speaker as an opportunity to clarify issues with which he/she may not be entirely familiar (Metcalfe, Wilson, \& Joham, 2002; Wortmann, 1992). Guest speaker events also have weaknesses. Any talk, whether from a lecturer or a guest speaker, is often a one-way verbal communication. When students sit and listen politely to guest speakers, they may not obtain optimum learning from the speaker (Jones \& Borst, 2011). As such, students do not capitalize on the presence and availability of the speaker to enact a two-way communication (Olson, 1988). Receiving a guest speaker thus has the potential to benefit students, instructors, and the guest speaker themselves (Metrejean, Pittman, \& Zarzeski, 2002), but the one-way communication that is commonly experienced limits these benefits.

How can an educator overcome these limits thereby increasing the benefits of a speaker event? One way to do this is to structure the guest speaker event so that it resembles that of a teaching case. We propose the live teaching case method as a way to achieve this.

\section{The Live Teaching Case Method}

\section{An Introduction}

The live teaching case method is a hybrid between a guest speaker event and a teaching case. A guest speak event is categorized as a typically passive-like teaching/learning technique while a teaching case is an active one (Rodrigues, 2004). Using a hybrid of the two transforms the passive-like guest speaker event into an active one. Instead of having an invited guest speak about a particular topic, the guest (termed here the animator) recounts a real life decision point that they encountered in their job, the context surrounding that decision point, and asks the class "What should we have done?" Then, the class uses a case-style discussion to analyse the decision point and make recommendations. The animator participates in this discussion and can provide addi- 
tional details on the context as needed. Finally, the animator reports on what they actually did. This process may occur for one or several decision points.

The live teaching case method is different from a written case as it is the animator who is verbally presenting the case. The instructor and animator together animate the case discussion. This method alleviates several shortcomings of the teaching case method mentioned earlier as an individual with personal and specific and authentic knowledge of the situation is presenting the case live. For the students, this creates a much more realistic sense of the case. Further, students are able to ask additional in-depth questions about the context, the answers of which are not limited by the pages of a written case and its teaching notes. Finally, there can be a deeper discussion as the animator can use additional contextual details to either support or challenge the students' decisions.

The live case method also alleviates several shortcomings of the guest speaker method. First, it is much more structured. The instructor and animator work together closely to develop the live case and a teaching plan (which corresponds to the written teaching note used in the traditional case method). Because of the teaching plan and the approach by decision point, the discussion is much more directed than for regular guest speaker event. It also gives students a much more active role compared to listening to a guest speaker, enabling them to become immersed in the story and its decision points.

\section{The Live Teaching Case Method: In Depth}

This section outlines the process of using a live teaching case, from initiation to wrap-up.

\section{Initiating}

The first step is for the instructor to approach a potential animator to see if they are interested in being part of the class. The instructor should show potential animators a general outline of the course content to see if they have a story which fits one of the pedagogical objectives. If there is a fit between their experiences and the course content, the instructor communicates to them the basics of the live teaching case approach and clearly outlines their responsibilities if they agree to take part (see the section for animators below). If there is willingness on the part of animators to openly discuss and analyze their experiences, the instructor arranges a meeting to prepare for and plan the live case.

\section{Planning the decision points}

This planning session between the instructor and animator is essential to selecting and developing key decision points which fit with the instructor's pedagogical objectives. The instructor should encourage the animator to brainstorm four to six key managerial decisions in which they have been involved and which apply to the course content. Then, they should discuss the various situations and any course theory that could be used to help the students analyze the decision points. Two or three of the decision points which best match the pedagogical objectives should be selected. For each decision point selected, the animator should report on what decision was actually made and the result. The animator knows what was actually decided but can work with the instructor to see if course materials would suggest any viable alternatives. It may even be useful for the instructor to develop a table of possible responses and analyze the appropriateness of each response. The instructor should either develop this with the animator or verify the table with the animator to see if he or she agrees. Such an analysis would become part of the teaching plan and would not be provided to the students (much like the teaching notes for a traditional case). 


\section{Student readings and pre-course materials}

Student preparatory readings and pre-course materials should be determined by the instructor with input from the animator. For students to be able to meaningfully contribute to the live case discussion, students need to prepare for the live case in advance by reading, reviewing materials, and preparing answers to discussion questions. For example, if the animator's topic is a project to implement a workplace collaboration system, students could read articles or websites that explain these systems, their general purpose, the different types available, their vendors, and the market in general. Students could also be assigned materials specific to the organization in which the animator works or worked (for example, the organization's mission, vision, website, and organizational chart). Further, the animator or instructor could prepare a short one-page introduction to the live teaching case and the major players involved. Depending on the type of reading materials received, students could also be asked to prepare answers to three to five discussion questions (for example, "compare and contrast organization X to other organizations in their industry" or "compare and contrast organization X to other organizations we have seen in class").

\section{Initial presentation}

As the live case day approaches, the instructor should review the content of the animator's initial presentation. Since the students will be listening to this presentation instead of reading the text of the teaching case, the content of this presentation is very important. The instructor further needs to be prepared to moderate the discussion of the decision points and so needs to know these points in depth. A fairly short 20 minute initial presentation of the animator and the business context is suggested in order to keep the students engaged and active. More details of the live case can be revealed in the discussion that follows. Content of this initial class presentation should include a description of the involved organization and its industry, a description of the context and its major players, a brief history, and timeline of key events.

\section{Initial discussion}

After the initial presentation, a general discussion should be held to give the students and animator a chance to become familiar and comfortable talking to one another. Discussion can focus on questions provided to the students with the pre-course materials or provided directly before or after the initial presentation. This is a good opportunity for students to ask the animator for clarity about particular sections of the story.

\section{Presentation and discussion of managerial decision points}

Once the general ideas of the case are understood and the students and animator have had a chance to get to know one another, the animator can present one of the major managerial decision points. They should explain the context of what was happening, what their options were (if known at the time), how they felt, how long they had to make the decision, etc. They should not tell the class what they actually did. Then, with instructor guidance, students can start to discuss the problem and what they would have done in that situation. The animator can contribute as well, indicating what ideas were not an option or would not have worked and why. As with a traditional case, one option is to have students break into groups for this discussion. Once the discussion is finished, the animator should report on what decision was actually made and the result. They may also indicate other options which may have worked given their understanding of the context. This process should be repeated for each managerial decision point or until the allotted class time has elapsed. 


\section{Wrap-up}

After covering the various decision points, the animator can give a general epilogue describing what has happened since or the current state of the issue in that organization. The instructor should also provide a final summary, reminding students of the major learnings and links with course content.

\section{The Live Teaching Case Method Applied}

In this section, we demonstrate how the live teaching case method can be applied to three different IS courses in three different ways, namely, an IS project management course, a systems analysis and design course, and a course on enterprise system implementation. In the proposed live teaching case for the IS project management course, the animator visits the classroom for the duration of one class. In the systems analysis and design course, the animator visits the classroom for the duration of one class but continues to interact with the students throughout the semester. In the enterprise system implementation course, the students are more fully immersed in the live case by visiting the animator onsite at his or her organization and the discussion of the live case lasts for an entire semester. In the IS project management and enterprise system implementation courses, the live teaching case approach has already been used. In systems analysis and design, we have described how the live teaching case could be used in such a course.

\section{IS Project Management}

This course is part of the recommended IS curriculum (Topi et al. 2010) and covers the processes, methods, and techniques project managers use to manage IS projects. The course involves a group of 20-30 undergraduate students in the third or fourth year of completing their undergraduate degree in information systems. In terms of pedagogical methods, this course often uses a combination of technical exercises and teaching cases. Two live teaching cases have been used in this course; a project manager recounting his first experience as a project manager and a sponsor of an agile project. Both animators visited the classroom for the period of one class.

\section{Initiating}

Potential animators for an IS project management course include project managers, project sponsors, project team members, or members of the organization's project management office. The project manager and sponsor mentioned above were approached by the instructor because they were currently involved in projects, had done guest speakers presentations previously, and had been very open and engaging about their experiences in these previous presentations.

\section{Planning the decision points}

In face-to-face meetings with each animator, three decision points were planned for each live teaching case. For the novice project manager, he had been a technical developer with no project management experience or education and was offered the job of managing a new project on which his team was embarking. The three selection decision points were (1) whether or not to accept a job managing his friends (the other developers he had worked with), (2) how he should handle his first official meeting with the team, and (3) what to do when the project fell behind schedule. These are common issues faced by new project managers. For the agile project sponsor, the three decision points were (1) what to do when given the role of project sponsor for an agile systems development project that is already underway and already behind schedule, (2) how to find political support for a project that was not even known to top management, and (3) how to prepare the organization for the major changes that would come with implementing this new system. 


\section{Student readings and pre-course materials}

For advance materials, students were given the link to a short video which described the company for which the project manager had worked. For the project sponsor, students were given several readings on agile projects. In addition, the instructor compiled information from a series of organizational websites to create a six page document which covered basic information on the organization and its mission, the type of software which had been selected for implementation, and the project structure and objectives.

\section{Initial presentation}

In an IS project management course, the initial presentation could cover elements such as:

- Description of the organization and its industry,

- Description of the project and its major players (organization charts, etc.),

- Description of the project context (organizational, team, or personality factors for example),

- Presentation of some organizational documents if possible (extracts of the business case, project management plan, etc.),

- Description of the timeline of key events.

In the live teaching cases already experienced, both animators gave approximately 20 minute presentations (on different class dates) which covered these topics. In addition, they explained their own background and experiences prior to the case.

\section{Presentation and discussion of managerial decision points}

For both animators, a decision point would be presented and students would be given a few minutes to note their response or discuss with the student behind them. Then, the instructor called on students and noted their responses on the board. The instructor noted each different option across the top of the board and in the column under each option made notes about their advantages and disadvantages. Next, the animator commented on each of the options, giving additional information where appropriate to demonstrate whether or not the option was a viable one which gave rise to more discussion with the students. The animator then told the class what he actually did as well as what he wished he had done (which were sometimes the same option). Finally, the instructor provided a theoretical model, framework, or approach which could be used when faced with a similar problem. In the example of the project manager's second decision point regarding how to manage the first meeting with the project team, Tuckman's (1965) model of group development was used.

\section{Wrap-up}

For the wrap-up, both animators formally presented an epilogue of the project as well as how what they learned during these experiences changed how they managed future projects. Students were also invited to ask any further questions they had about the projects or the animators' career in general.

\section{Systems Analysis and Design}

Systems Analysis and Design is a core and important course in IS curriculum which should be taught in all business schools offering an IS program (Topi et al., 2010). This course is commonly offered in the first or second year of an undergraduate degree. The main objective of this course is to learn how to systematically analyze and understand business processes and how to translate 
such understanding into the design and development of an information system that will adequately support these business processes.

Our institution's version of the course uses a methodology which consists of providing a detailed description of the different steps, activities, and tools involved in systematic analysis and design. The key activities involved in the process of systems analysis and design are as follows:

- Understanding business requirements

- Collecting information about business processes and information systems

- Analyzing a business environment

- Specifying business requirements

- Modeling business processes

- Modeling information systems

- Communicating with different functional stakeholders

- Critically assessing the feasibility/implementability of an IS solution

The main premise of the course is that business processes and information systems are intertwined and that optimal IS design requires a systematic and astute understanding of the business processes and environment for which the system is built.

Currently, in order to develop the necessary analytical skills to understand business requirements and business processes, the course uses a traditional written teaching case which provides a detailed description of different business processes within one organization. The written teaching case also explains the business problem(s) and provides some information related to the organizational environment. In order to reach the above described pedagogical objectives, the process of using a live teaching case could be implemented as outlined below.

\section{Initiating}

The first step is for the instructor to approach potential animators. An appropriate animator for such a course would be a business process owner, super user, or functional area manager. The animator must have an in-depth knowledge of at least a subset of the business processes of their organization.

\section{Planning the decision points}

Three main decision points will be developed and planned with the animator. The first decision point is related to the preliminary phase of systems analysis and design. For this decision point, students will be asked to provide an initial report analyzing the business environment and specifying the process requirements which will then be contrasted with the analysis performed by the animator's organization. The second decision point is related to an in-depth diagnosis phase. At this stage, students will be asked to provide a more detailed business analysis including process models and costs estimations which will be discussed and evaluated with the animator. Finally, the third decision point will be related to the design of the information system considered by the organization. At this stage, students will be asked to provide detailed system and database models which will be evaluated with the animator or another stakeholder of the same organization. Discussions related to the three decision points need not be organized solely in the classroom and could be planned through group conference calls, meetings, or online asynchronous discussion forums set up specifically for the course.

\section{Student readings and pre-course materials}

Besides regular course readings, students will be assigned materials specific to the organization in which the animator works or worked including the organization's mission, vision, and description 
of the IS infrastructure and IS policies. In addition, a few questions would be assigned which would allow the students to become familiar with the organization such as "What is the business strategy of organization X?" and "What should be some of the key business process which would be needed to support this strategy?"

\section{Initial presentation}

A short initial presentation (e.g., 30 minutes) of the animator and the business context will be planned. After this presentation, a general discussion will be held to give students the opportunity to become familiar with the animator and to develop their communication and information gathering abilities. The discussion will focus on questions provided to the students with the pre-course materials and also on questions provided during the initial presentation. The first presentation and discussion will be planned for a 3 hour class period.

\section{Presentation and discussion of managerial decision points}

The first decision point will be presented and discussed in the same class as the initial presentation. For the second and third decision points, an asynchronous online discussion board will be developed for the course and the instructor will moderate the students' discussion (with the animator's input). Students will be able to pose questions about each of the three decision points at the appropriate time during the course (in line with assignment due dates).

\section{Wrap-up}

As the three decision points will be planned during a full semester, both the animator and the instructor will give a joint presentation at the end the semester to remind students of the major learnings and links with the core concepts of the systems analysis and design course.

\section{Capstone ERP Implementation Course}

The teaching objective of the capstone enterprise resource planning (ERP) implementation course is to provide real life experience of the full life cycle of implementing an enterprise system, from system design and analysis, to reengineering, technical configuration and testing. Such a course is usually reserved for an undergraduate student's final year of study. Students are able to apply knowledge acquired in previous IS courses in a business problem solving context. Nonetheless, most ERP teaching cases cannot be used to achieve these goals. Written cases generally cover topics such as ERP selection (Austin, Nolan, \& Cotteleer, 2002), deployment (Brown \& Vessey, 2001), and implementation (Compeau, Mitchell, Drotos, Incze, \& Vas, 2008; McAfee, McFarlan, $\&$ Wagonfield, 2004) that do not allow students to develop real life problem solving skills related to the entire implementation process. As well, the level of complexity related to the technological challenges and implementation solutions needs to be understood in greater detail than the level of detail offered by written cases.

For example, instructors often use reengineering cases to achieve their pedagogical objectives. However, such cases only offer information on problems at a business process level. This is a partial approach as it does not allow students to develop a general view of the system implementation life cycle. Further, these cases are not tailored to the ERP context. As a result, important functional details are missing from these cases and their scope is generally too broad to allow students to actually use and configure the ERP technology. Though some pedagogical materials involve detailed technological requirements such as detailed implementation scripts, they are more exercise-like documents that are only designed to train analysts to read instructions effectively (Wagner \& Monk, 2008). In sum, a key limitation of the written case for this style of ERP implementation capstone course is that they do not sufficiently mirror the real life context of an ERP implementation. 
During the last five years, several variations on the live case method were used in our ERP implementation course. In our undergraduate and graduate level capstone courses on ERP implementation, we were able to involve several companies - including Ratiopharm Canada, IBM Canada, Hydro-Québec and l'Oréal Canada - to help us provide our students with a real life context of ERP implementation. The process of how the live teaching case method was applied in this course is described below.

\section{Initiating}

Potential animators for this course are IT individuals in the company with enough power to provide physical access to the company as well as all of the required information. In the case of Ratiopharm, the live teaching case was organized with the CIO. Companies with ERP systems are often interested in participating in the live teaching case in this course as it allows them to meet and see the performance of students in the class who are future potential job candidates.

\section{Planning the decision points}

In this course, the live teaching case can be designed around several different decision points: the choice of solution (usually related to an ERP) to respond to the problem, the configuration and modifications required, and the implementation plan. A pre-meeting between the instructor and the representative of the company (who will usually also be the animator) is scheduled and the instructor helps the company to determine the nature and scope of these decision points. For example, in the case of l'Oreal, the decision was made that the case would cover the company's new product launch campaign. Generally, the chosen case describes an implementation that is underway or an implementation that has recently been performed. In other words, the company has a good knowledge of what the decision points were, the options that were available, and the decisions made to resolve the problem.

\section{Student readings and pre-course materials}

The instructor also writes a document to provide context on the company and its business requirements. There are two reasons why this document is written instead of using documentation from the organization itself. First, unnecessary details are scoped out of the case to help students focus on the essential part of the problem and ensure the feasibility of the case for the time frame of a university course. Also, frequently a company will prefer not to disclose certain confidential information. Based our experience, this document does not seem to alter the authenticity of the case. The document is then distributed to the students in order to prepare for the meeting with the company.

\section{Initial presentation}

To further familiarize the students with the business context, a visit to the company is organized early in the semester. This allows students to see the business processes of the company in action before investigating the managerial decision points. In the Ratiopharm case, a visit was organized to their plant in order to observe the pharmaceutical manufacturing and warehousing processes.

\section{Presentation and discussion of managerial decision points}

An on-site meeting is organized with the animator in which the animator presents the first managerial decision point by describing the organizational situation prior to the implementation. The animator does not talk about the options considered to solve the problems or about the actual business solution that was implemented. The students are then invited to ask questions to better understand the situation and elicit the needs of the company, which generally leads to engaging and interesting discussions. Students are well aware that if they do not ask the right questions and 
obtain the required information, they will not be able to complete the implementation. In the case of Ratiopharm, we were able to organize meetings with real life users who provided students with information related to the former "AS-IS" context, just as they would be if interviewed in a real life implementation.

\section{Wrap-up}

At the end of the course, students are asked to present their solutions as well as a working prototype of their implementation. The animator is invited to attend these presentations. At the end of the presentations, a final debriefing with the company is organized where the animator presents the solution chosen by the company and comments on the solutions provide by the students.

\section{Discussion}

As described above and shown in Figure 1, the live teaching case method can be applied in various ways. In particular, students can experience varying levels of immersion in the case and their interaction with the case can involve varying durations.

\begin{tabular}{|c|c|c|}
\hline \multirow{2}{*}{$\begin{array}{l}\text { high } \\
\text { Level of immersion } \\
\text { low }\end{array}$} & & $\begin{array}{l}\text { Example: } \\
\text { Enterprise system im- } \\
\text { plementation course }\end{array}$ \\
\hline & $\begin{array}{c}\text { Example course: } \\
\text { IS project manage- } \\
\text { ment }\end{array}$ & $\begin{array}{c}\text { Example course: } \\
\text { Systems analysis and } \\
\text { design }\end{array}$ \\
\hline
\end{tabular}

Figure 1: Various applications of the live case method

\section{Live Teaching Case: Indications of Success}

In the different applications of this method, there are some indications from students, instructors, and guest animators that the use of the live teaching case method was a success. To collect information from the various perspectives, we interviewed two instructors and one animator who had used the live teaching case method. In addition, we gathered information from student evaluations of the courses.

From the student perspective, for example, $50 \%$ of students in the IS project management course favorably mentioned the live teaching cases in their written evaluations of the course (there were no negative mentions). Students reported that the live teaching cases were "very interesting", "brought a lot of value to this course", allowed a "very interesting balance between theory and practice", and were a "very fresh and effective way to enrich learning with real-life experienced guests". They further recommended including more live teaching cases in future courses. The IS project management instructor reported increased student engagement during the live teaching case sessions while echoing the students' assertions that it was a good way to bridge theory and practice. The enterprise system implementation course instructor found that the live teaching case method was extremely effective as it allows retention of the richness and complexity of the business problem, while shaping the experience for academic purposes. The guest animator who was interviewed after the live teaching case experience reported that he enjoyed the experience and would be open to animating further live teaching cases in the future. 


\section{Benefits of Using a Live Teaching Case}

Based on the interviews with two instructors and one animator as well as on our experiences, several benefits of and recommendations for using this method were identified. These benefits as compared to the guest speaker event and the traditional teaching case are highlighted in Table 1.

As shown in Table 1, a live teaching case method allows the animator to convey more contextual cues to the students. As explained by one of the instructors we interviewed, important contextual details can be shared such as those that are difficult to express in writing (e.g., the personalities of the major case actors). Having access to contextual cues is important to students as it helps them develop a more refined understanding of the decisions made. Further, a key skill in the IS curriculum (Topi et al. 2010) is mastering information collection techniques such as interviews, questionnaires, observation, and documentation. Though traditional teaching cases help develop analytical skills related to documentation, they cannot foster the development of more commonly used data collection techniques such as interviews. The animator we interviewed highlighted this point, suggesting that in a live teaching case the students "have access to all the information they judge to be pertinent;" if they are missing a particular detail, they can ask a question and have an immediate response. This demonstrates that the live teaching case approach allows students to develop key information collection skills. In addition, the animator suggested that a live teaching case strengthens the communication skills of the students as they have the opportunity to discuss with and present their proposed ideas to the animator and get instant feedback. Regarding a final point, both instructors found that a live teaching case fosters high appropriation and engagement levels from the students as compared to the guest speaker event or a traditional teaching case (Rodrigues, 2004) which are essential components of a successful learning process.

Table 1: Comparing Methods

\begin{tabular}{|l|c|c|c|}
\hline & $\begin{array}{c}\text { Guest speaker } \\
\text { event }\end{array}$ & $\begin{array}{c}\text { Traditional teaching } \\
\text { case }\end{array}$ & $\begin{array}{c}\text { Live teaching } \\
\text { case }\end{array}$ \\
\hline Contextual cues & Medium & Low & High \\
\hline $\begin{array}{l}\text { Development of infor- } \\
\text { mation collection skills }\end{array}$ & Medium & Medium & High \\
\hline $\begin{array}{l}\text { Development of com- } \\
\text { munication skills }\end{array}$ & Medium & Low & High \\
\hline $\begin{array}{l}\text { Students' appropriation } \\
\text { and engagement }\end{array}$ & Low & Medium & \\
\hline
\end{tabular}

\section{Recommendations for Those Using a Live Teaching Case}

In addition to the guidelines and illustrations given above, we have several recommendations regarding the fulfillment of each role - animator, instructor, and students - in the live teaching case approach. These recommendations are outlined in Table 2. Animators must be carefully chosen for the suitableness of topic as well as their ability and willingness to engage in a group discussion of a very important event in their life. They must also be willing to commit to the added time and effort required as compared to a traditional guest speaker event.

For this approach to work, instructors need to be willing take enough time co-planning and codeveloping the live teaching case with the animator. During the live teaching case, the instructor needs to maintain control and direction of the class while allowing the animator space and time to have input. Instructors cannot present their ideas as the only correct ones and must realize that the animator has special experience and knowledge in this particular case.

This method also requires cooperation and special skills from students. Students need to be coached in advance that this is very different from a traditional teaching case. Animators have a 
very personal connection with these stories and often they are an important part of how they see themselves in their career and life. Negative comments (regarding the situation, the organization, the people involved, etc.) are not allowed nor direct critiques of what was done. However, students can instead be encouraged to ask the animator about alternative options, what they would have done differently if facing this problem again, etc. Finally, animators and decision points that are accessible to students should be selected when possible. For example, "what should the CIO do?" is a question that is too high-level for a first year undergraduate class. If the animators or decision points are not accessible to students given their background, experience, and knowledge, students will think that the situation or options available do not apply to them and will become disengaged in the learning process.

\section{Table 2: Recommendations for each role}

\begin{tabular}{|l|ll|}
\hline Animator & $\begin{array}{l}\text { Carefully selected for suitability of topic as well as ability/willingness to } \\
\text { engage in a group discussion of their case. } \\
\text { Informed of the time, effort, and involvement required. }\end{array}$ \\
\hline Instructor & $\begin{array}{l}\text { - Needs to be willing to co-plan and co-develop. } \\
\text { - }\end{array}$ & $\begin{array}{l}\text { Needs to be willing to allow the animator the space and time to have input. } \\
\text { Students }\end{array}$ \\
$\begin{array}{l}\text { their story, avoiding negative comments or harsh judgments. } \\
\text { To enhance student engagement, the decision point should be accessible to } \\
\text { them. }\end{array}$ \\
\hline
\end{tabular}

\section{Conclusion}

When teaching Information Systems (IS), one of the crucial objectives is to make students understand the bridge between theory and practice (Kerr et al., 2003). Several pedagogical approaches have been used to accomplish this task and we propose the live teaching case as one possible method. We believe that the live teaching case approach alleviates several of the traditional case method shortcomings while maximizing the benefits associated with the presence of a guest speaker in class. Though future research is needed to provide quantitative indications of the methods' success for IS courses, the qualitative feedback obtained from the perspective of instructors, animators, and students provides some face validity for the success of this method. We hope that this paper will be used as a guide for any instructor wishing to use the live teaching case method to enhance the learning process in their classroom or for those who wish to further examine the impacts of this method.

\section{References}

Austin, R. D., Nolan, R. L., \& Cotteleer, M. (2002). Cisco System, Inc: Implementing ERP. Harvard Business School (9-699-022), 19.

Boyer, E. L. (1997). Scholarship reconsidered: Priorities of the professoriate (1st ed.). New York, NY: Jossey-Bass.

Brown, C. V., \& Vessey, I. (2001). NIBCO's Big Bang. Communications of AIS, 5, 1-42.

Butler, R. D. (1997). Using gender balance to enhance teaching effectiveness. Business Communication Quarterly, 60, 93-100.

Clarke, J., \& Gibson-Sweet, M. (1998). Enterprising futures: Training and education for small businesses. Education and Training, 40(3), 102-108.

Compeau, D. R., Mitchell, J., Drotos, G., Incze, E., \& Vas, G. (2008). Richter: Information technology at Hungary's largest pharma. Ivey, No 907E21, 22 pages. 
Connolly, T., \& Stansfield, M. (2006). Using games-based elearning technologies in overcoming difficulties in teaching information systems. Journal of Information Technology Education, 5, 459-476. Retrieved from http://www.jite.org/documents/Vol5/v5p459-476Connolly170.pdf

Glenwick, D. S., \& Chabot, D. R. (1991). The undergraduate clinical child psychology course: Bringing students to the real world and the real world to students. Teaching of Psychology, 18(1), 21-24.

Gordon, G. (1999). Managing the changes inherent in developing the learning society: Issues, choices and strategies. Quality Assurance in Education, 7(3), 141-149.

Hackney, R., McMaster, T., \& Harris, A. (2003). Using cases as a teaching tool in IS education. Journal of Information Systems Education, 14(3), 229-234.

Jones, K. J., \& Borst, M. B. (2011). The talk show approach to guest speaker presentation: A Structured process for engaging learners. Paper presented at the Edward C. Moore Symposium on Teaching Excellence, Indianapolis, IN.

Joplin, L. (1995). On defining experiential education. In K. Warren, M. Sakofs \& J. S. Hunt (Eds.), The theory of experiential education (pp. 15-22). Dubuque, IA: Kendall/Hunt Publishing for the Association for Experiential Education.

Kamoun, F., \& Selim, S. (2007). A framework towards assessing the merits of inviting IT professionals to the classroom. Journal of Information Technology Education, 6, 81-103. Retrieved from http://www.jite.org/documents/Vol6/JITEv6p081-103Kamoun223.pdf

Kerr, D., Troth, A., \& Pickering, A. (2003). The use of role-playing to help students understand information systems case studies. Journal of Information Systems Education, 14(2), 167-171.

Leenders, M. R., Mauffette-Leenders, L. A., \& Erskine, J. A. (2001). Writing cases $\left(4^{\text {th }}\right.$ ed.). London, Ontario: Ivey Publishing.

Leonard, D. C. (1980). Some suggestions for having guest speakers in a technical writing course. Technical Writing Teacher, 7, 64-65.

Maglitta, J. (1996). IT schools need improvement. Computerworld, 30(8), 78-83.

Mauffette-Leenders, L. A., Erskine, J. A., \& Leenders, M. R. (2001). Learning with cases (2nd ed.). London, Ontario: Ivey Publishing.

McAfee, A., Dessain, V., \& Sjoman, A. (2007). Zara: IT for fast fashion. Harvard Business School (9-604081), 23.

McAfee, A., McFarlan, F., \& Wagonfield, A. B. (2004). Enterprise IT at Cisco. Harvard Business School (No 9-605-015), 13.

Metcalfe, M., Wilson, J., \& Joham, C. (2002). Critique skills as the core competency of IS academics. Paper presented at the Informing Science + IT Education Conference, Cork, Ireland.

Metrejean, C., Pittman, J., \& Zarzeski, M. T. (2002). Guest speakers: Reflections on the role of accountants in the classroom. Accounting Education, 11(4), 347-364.

Olson, L. E. (1988). The question approach to guest speakers. Journal of Education for Library and Information Science, 28(4), 313-316.

Rivard, S., Aubert, B. A., Patry, M., Paré, G., \& Smith, H. A. (2004). Information technology and organizational transformation: Solving the management puzzle. Burlington, MA: Elsevier.

Rodrigues, C. A. (2004). The importance level of ten teaching/learning techniques as rated by university business students and instructors. Journal of Management Development, 23(2), 169-182.

Tapscott, D. (2008). Grown up digital: How the net generation is changing your world. New York, NY: McGraw-Hill.

Topi, H., Valacich, J. S., Wright, R. T., Kaiser, K. M., Nunamaker, J. F., Jr., Sipior, J. C., \& de Vreede, G. J. (2010). Curriculum guidelines for undergraduate degree programs in Information Systems. Associa- 
tion for computing Machinery (ACM) and the Association for Inofrmation Systems (AIS). Accessed

November 102011 at http://www.acm.org/education/curricula-recommendations.

Tuckman, B. (1965). Developmental sequence in small groups. Psychological Bulletin, 63(6), 384-399.

Wagner, B., \& Monk, E. (2008). Enterprise resource planning (3rd ed.). Cengage Learning: Boston.

Wortmann, G. B. (1992). An invitation to learn: Guest speakers in the classroom. The Science Teacher, $59(2), 19-22$.

\section{Biographies}

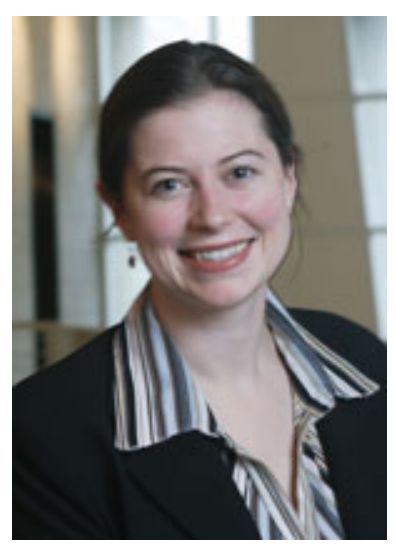

Ann-Frances Cameron is an assistant professor in information technology at HEC Montréal. She received her Ph.D. from Queen's School of Business at Queen's University in Kingston, Ontario. Her research interests include the use and impact of new technologies for inter- and intra-organizational communication. Her work has appeared in Organization Science, Computers in Human Behavior, Journal of Small Business Education, and Active Learning in Higher Education. Her teaching interests include IT project management and computermediated communication and she has experience teaching in the undergraduate, MBA, and doctoral programs at HEC Montréal.

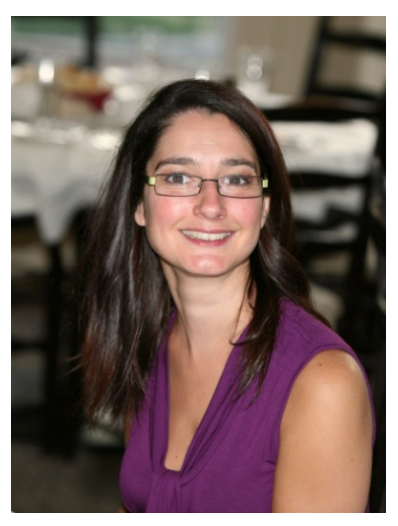

Dr. Marie-Claude Trudel is an Assistant Professor in information technologies at HEC Montréal. She holds a PhD in business administration (MIS) from the University of Western Ontario in London, Canada. Her research interests include health information systems, information systems for cultural organizations, IT education and research methods. She has published articles in the International Journal of Medical Informatics, Health Care Management Review, and BMC Health Services Research.

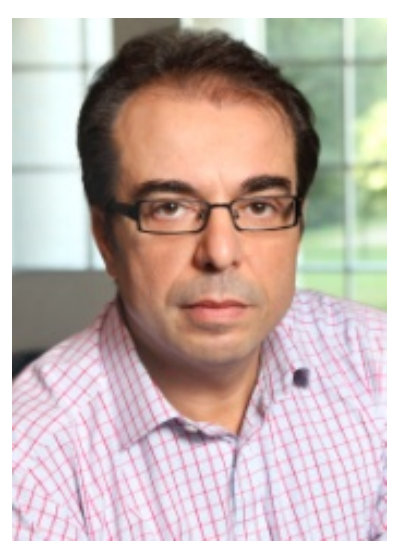

Ryad TITAH is an Assistant Professor of Information Systems at HEC Montréal. His main research interests are in information technology acceptance, use and impact in both public and private organizations. His work has been published in journals such as Information Systems Research, Information Technology and People, International Journal of Electronic Government Research, Journal of Management Information Systems and MIS Quarterly. His research has won several awards including a "Best IS Publication of the Year Award" granted by ICIS 2007 and its Senior Scholars, a "Highly Commended Paper Award" granted by Emerald Literati Network Awards of Excellence 2007, and the ACM SIGMIS Best dissertation award 2011. 


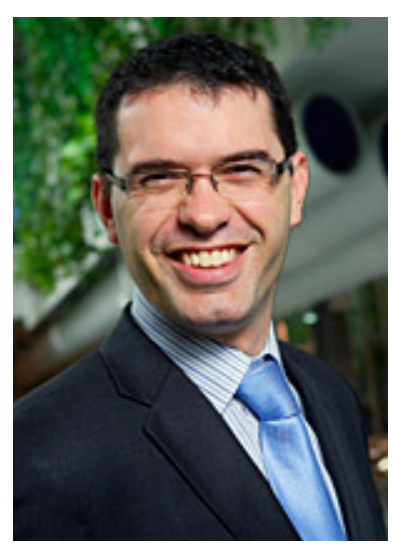

Dr. Pierre-Majorique Léger is an Associate Professor in information technologies at HEC Montréal. He holds a PhD in industrial engineering from École Polytechnique de Montréal and has done post-doctoral studies in information technologies at HEC Montréal and NYU Stern. $\mathrm{He}$ is the Director of ERPsim Lab, an R\&D center in the field of serious games for end-user IT training. He is also co-director of Tech3Lab, a business user experience lab in the field of NeuroIS. He is a cocreator of ERPsim, a simulation game to teach ERP concepts, which is now used in more than 200 universities worldwide and many Fortune 1000 organizations. 